\title{
Bezpieczeństwo społeczne jako dziedzina bezpieczeństwa narodowego
}

\section{Social Security as a Field of National Security}

\section{- Abstrakt •}

Bezpieczeństwo społeczne traktowane jest jako jeden z wielu sektorów (rodzajów) bezpieczeństwa narodowego. Jeszcze na początku lat 90. ubiegłego wieku $\mathrm{w}$ debacie o bezpieczeństwie państwa oraz w politycznej i strategicznej praktyce używało się terminu bezpieczeństwo państwa bez wyodrębniania pojęcia bezpieczeństwa społecznego. Dopiero po zakończeniu zimnej wojny w koncepcjach bezpieczeństwa dostrzeżono różnorodność zagrożeń. Koncepcje bezpieczeństwa zaczęto budować na znacznie szerszej niż militarna płaszczyzna. Obecnie standardem stało się podejście wielowymiarowego postrzegania bezpieczeństwa. W konsekwencji ogólny termin „bezpieczeństwo narodowe” ulegał dekompozycji na dziedziny i sektory. Problemy związane $\mathrm{z}$ bezpieczeństwem społecznym można rozpatrywać w różnych aspektach jako szczególny rodzaj bezpieczeństwa. W literaturze z zakresu nauk o polityce, ekonomii, socjologii czy też nauk o bezpieczeństwie funkcjonują różne pojęcia charakteryzujące tę kategorię. Problematyka bezpieczeństwa społecznego jest zagadnieniem złożonym i niejednorodnym, ponieważ jest to zjawisko badane na gruncie wielu dyscyplin naukowych. Praca jest próbą odpowiedzi na pytanie, czy bezpieczeństwo społeczne można zaliczyć do kategorii bezpieczeństwa narodowego.

\section{- Abstract •}

Problems related to social security can be seen in various aspects as a particular type of security. In the literature in the field of political science, economics, sociology or science of safety there are different concepts characterizing this category. The issue of social security is a complex and ambiguous-reproductive, because this phenomenon is dynamic and dependent on many factors. The work is an attempt to answer the question of what are the theoretical foundations of social security on the basis of the teachings of the safety and whether it can enter other, closely related to national security category, concepts, eg. social security of the nation. The reference point for discussion is the system of national security. The author proposed a definition of social security of the nation and pointed out the main elements characterizing this concept. The rationale for the choice of topic is also a need to shape the real way to solve scientific problems of modern science on the basis of safety, including those related to operationalization of concepts and circumscribe an area of knowledge (or unawareness), which should focus on the search for representatives of this new scientific discipline. 
W Strategii Bezpieczeństwa Narodowego wskazano, że jest ważnym elementem bezpieczeństwa narodowego.

Słowa kluczowe: bezpieczeństwo, teoria bezpieczeństwa, bezpieczeństwo narodowe, bezpieczeństwo społeczne
Keywords: security, theory of security, national security, social security

\section{Wstęp}

Jeszcze do niedawna kategoria „bezpieczeństwo społeczne” nie funkcjonowała w obszarze nauk zajmujących się problemami bezpieczeństwa narodowego. Od pewnego czasu zaczęto identyfikować tę problematykę zarówno z ochroną fizycznego trwania, integralności terytorialnej i trwałości instytucji państwa, jak i z zapewnieniem swobód rozwojowych, takich jak nieskrępowany rozwój społeczno-gospodarczy i kulturalny, wzrost jakości życia, osiągnięcie dobrobytu (Skrabacz, 2012). W Biakej Księdze Bezpieczeństwa Narodowego RP wyróżniono bezpieczeństwo społeczne jako jedną z czterech dziedzin bezpieczeństwa (obok obronnej, ochronnej i gospodarczej).

Bezpieczeństwo społeczne jest kategorią niejednorodną, co przy braku uzgodnionego stanowiska różnych dyscyplin naukowych co do treści opatrywanej tym terminem w konsekwencji prowadzi do różnorodnego jego postrzegania. Istnieją też mniej lub bardziej udane próby zdefiniowania tego pojęcia na gruncie nauk o bezpieczeństwie.

Analiza literatury przedmiotu wskazuje, że pojęcie bezpieczeństwa społecznego na gruncie polskim pojawiło się w pracach odnoszących się do teorii polityki społecznej, bezpieczeństwa międzynarodowego, a dopiero później narodowego (Kukułka, 1982; Kitler, 2011) jako istotny element bezpieczeństwa wewnętrznego. Jeżeli przyjąć, że podział na bezpieczeństwo wewnętrzne i zewnętrzne zdeterminowany jest źródłem zagrożenia (od wewnątrz/z zewnątrz), to w tym klasycznym pojmowaniu bezpieczeństwa bezpieczeństwo społeczne sytuowałby się w obrębie wymiaru wewnętrznego.

Bezpieczeństwo społeczne wiąże się z prawdopodobieństwem wystąpienia niepożądanych zjawisk (problemów) społecznych oraz ograniczeniem ryzyk związanych z przetrwaniem i jakością życia w sferze ekonomicznej i kulturowej. W ten sposób można powiedzieć, że bezpieczeństwo społeczne oznacza zdolność/funkcję państwa do przeciwstawiania się zagrożeniom wewnętrznym w obszarze społecznym. Jednak określenie poziomu zagrożeń w obszarze bezpieczeństwa społecznego jest przedsięwzięciem złożonym, wymagającym analizy wielu czynników, w tym 
czynników niemierzalnych (subiektywnych), trudnych do skwantyfikowania. Stosunkowo najłatwiejszym do oceny jest poziom potrzeb socjalnych. Niezaspokojone potrzeby mogą zamienić się w problemy społeczne, a te można traktować jako źródło niepokojów społecznych. Rozwiązanie ich należy w głównej mierze do administracji publicznej. W ten sposób bezpieczeństwo społeczne może być kojarzone z zadaniami organów publicznych, ich kompetencjami oraz rolą w systemie bezpieczeństwa państwa. W takim rozumieniu (Misiuk, 2013) pojęcie to będzie oznaczało zespół instytucji chroniących obywateli przed zagrożeniami egzystencji i dezorganizacji społecznej.

W ramach działów administracji rządowej (t.j. Dz.U. z 2017 r. poz. 888, 1086) oraz zgodnie z przyjętą w Polsce strukturą działalności państwowej można wyodrębnić sektory bezpieczeństwa narodowego, takie jak np. bezpieczeństwo militarne, publiczne, społeczne ( $w$ tym socjalne), gospodarcze (w tym energetyczne, finansowe) czy bezpieczeństwo kulturowe (dziedzictwo, nauka, edukacja, media itp.). Bezpieczeństwo społeczne można przypisać do działów: praca, rodzina i zabezpieczenie społeczne.

Warto jednak zaznaczyć, że niezależnie od szczegółowości zapisów kompetencji głównych organów władzy wykonawczej zawsze pozostanie obszar działania wymagający współpracy kilku organów w imię wyższych celów, a takim celem niewątpliwie jest bezpieczeństwo społeczne.

\section{Bezpieczeństwo społeczne w ujęciu normatywnym}

Termin bezpieczeństwo społeczne występuje w aktach normatywnych zarówno rangi ustawowej, jak też w aktach prawnych niższego rzędu. W Konstytucji RP powiązano je z zabezpieczeniem społecznym, o czym stanowi art. 67, w którym „obywatel ma prawo do zabezpieczenia społecznego w razie niezdolności do pracy ze względu na chorobę lub inwalidztwo oraz po osiągnięciu wieku emerytalnego. Zakres i formy zabezpieczenia społecznego określa ustawa”. Ponadto „obywatel pozostający bez pracy nie z własnej woli i niemający innych środków utrzymania ma prawo do zabezpieczenia społecznego, którego zakres i formy określa ustawa”.

Do obowiązków państwa należy między innymi dbałość o życie, zdrowie i mienie obywateli oraz zaspokajanie ich potrzeb przynajmniej w wysokości odpowiadającej minimum życiowemu. W Polsce na temat rozumienia tego terminu wielokrotnie wypowiadał się Trybunał Konstytucyjny, wskazując, że pojęcie to obejmuje całokształt świadczeń, jakie ze środków publicznych są przyznawane obywatelowi znajdującemu się w potrzebie (K 7/95, OTK 1996). W ramach tej 
instytucji możliwe jest wyodrębnienie jej trzech kategorii, które razem tworzą system zabezpieczenia społecznego. Są to: 1) ubezpieczenia społeczne; 2) zaopatrzenie społeczne i jego ostatnie ogniwo mające uzupełniający charakter; 3) pomoc społeczna (Gierszewski, 2013a).

Istotą działań ochronnych istotnych dla bezpieczeństwa państwa jest zapewnienie warunków dla utrzymywania ładu konstytucyjnego, wewnętrznej stabilności państwa, bezpieczeństwa powszechnego i porządku publicznego, zarówno wspólnych, jak i indywidualnych zasobów materialnych i niematerialnych, a także funkcjonowania infrastruktury krytycznej (Strategia Bezpieczeństwa Narodowego, 2014).

Natomiast działania w obszarze bezpieczeństwa społecznego mają na celu stworzenie bezpiecznych warunków godziwego życia obywateli oraz rozwoju duchowego i materialnego narodu.

\section{Bezpieczeństwo społeczne w poszerzonym ujęciu bezpieczeństwa}

Stabilność i bezpieczeństwo państwa gwarantowane są przez wiele czynników, które w jednych paradygmatach mają kluczowe znaczenie, a w innych są nawet całkowicie pomijane lub marginalizowane. Wielu badaczy problemu uważa, że najdoskonalszą jak dotąd formą zabezpieczenia potrzeb człowieka i grupy społecznej w tym zakresie jest państwo (Kitler, 2010).

Jeden z czołowych badaczy problemu Barry Buzan stwierdził, że po rozpadzie dwubiegunowego świata należy bezpieczeństwo traktować holistycznie ze względu na chociażby internacjonalizacje zagrożeń (Floyd, 2017). Zagrożenia społeczne, jak powszechnie wiadomo, są nierozerwalnie związane z pojęciem bezpieczeństwa, chociaż mają różny charakter, siłę i skalę oddziaływania na różne podmioty bezpieczeństwa, które można objąć analizą pod kątem relacji społecznych czy środowiskowych (Biernat, Gierszewski, 2013).

Określenie celów bezpieczeństwa społecznego jest również niezwykle ważne dla funkcjonowania państwa. Strategiczny Przegląd Bezpieczeństwa Narodowego podkreślił, że system bezpieczeństwa państwa należy analizować również pod kątem ewolucji zagrożeń oraz zdiagnozowania obszarów, które stanowią największe wyzwania dla utrzymania stabilności państwa. Strategia Bezpieczeństwa Narodowego z 2014 r. bezpieczeństwo społeczne zalicza do podsystemu wsparcia i wiąże je m.in. z ochroną dziedzictwa narodowego, zagrożeniami demograficznymi czy bezpieczeństwem socjalnym (Strategia Bezpieczeństwa Narodowego, 2007). 
Bezpieczeństwo społeczne postrzegane jest z jednej strony w wymiarze egzystencjalnym jako ochrona podstaw życia ludzi, zaspokajanie ich potrzeb oraz umożliwianie realizacji aspiracji życiowych. $Z$ drugiej strony związane jest z oceną działalności instytucji powołanych do minimalizowania różnorodnych zagrożeń społecznych, o czym już wspomniano. Określenie przymiotnikowe „społeczne” oznacza rodzaj bezpieczeństwa w ujęciu przedmiotowym. Możemy dalej zadać pytanie, ale uzależnione jest od kogo? czego? Społeczeństwa, aktywności własnej jednostki czy państwa? Czy stanowi zbiór odrębny, czy jest częścią szerszego zbioru (systemu)? Kto i w jakim zakresie ma stwarzać warunki umożliwiające istnienie, rozwój i normalne funkcjonowanie jednostki, grupy społecznej w państwie?

Analiza literatury przedmiotu pozwala zwrócić uwagę, że bezpieczeństwo społeczne jest dotychczas definiowane niespójnie. Na przykład, gdy mówimy o ochronie społeczeństwa przed zagrożeniami, to może poprawnie powinno określać się jako bezpieczeństwo społeczeństwa w państwie oznaczające stan obiektywny, subiektywnie odzwierciedlany w społecznej świadomości. Natomiast gdy mówimy bezpieczeństwo społeczne, to myślimy o pomocy dostarczanej jednostkom i grupom społecznym w ramach określonego systemu, a więc wiążemy je z pomocą w wymiarze ekonomicznym (socjalnym; Hofreiter, 2012).

Bezpieczeństwo społeczne kojarzone jest też z ochroną tożsamości narodowej określanej jako zdolność do utrzymywania kultury, zwyczajów czy języka. W takim ujęciu wartością chronioną jest nie tylko zapobieganie społecznej oraz ekonomicznej nędzy, ale tożsamość narodowa i jej zagrożenia związane np. z migracją.

Pomimo zbliżonych nazw societal security (bezpieczeństwo tożsamości, społecznościowe), zakorzenienia do social security (bezpieczeństwo socjalne) nie są to pojęcia tożsame. To pierwsze dotyczy procesu konstruowania tożsamości grupowej (historii oraz kultury narodu). Natomiast bezpieczeństwo socjalne utożsamiane jest raczej z gwarancją zaspokajania istotnych potrzeb społecznych. Według przedstawicieli szkoły kopenhaskiej societal security miało związek z ochroną przed niepożądanym wpływem innych kultur, a social security ze zdolnością społeczeństwa do przetrwania (Weaver i in., 1993).

Między tymi pojęciami istnieje funkcjonalne powiązanie tylko wtedy, gdy warunki socjalne wpływają na zbiorową samoidentyfikację. Źródłem konfliktu w obszarze bezpieczeństwa społecznego może być sama odrębność kulturowa, samo zróżnicowanie ekonomiczne albo tożsamość narodowa w połączeniu ze zróżnicowaniem ekonomicznym (Gierszewski, Piwowarski, 2016).

Współcześnie bezpieczeństwo społeczne ulega poszerzaniu w płaszczyźnie pionowej („obiektem bezpieczeństwa staje się, obok państwa, grupa społeczna lub pojedyncza osoba”) oraz poziomej („,bezpieczeństwo obejmuje sektory pozamilitar- 
ne, które tradycyjnie do niego nie należały, w tym czynniki społeczne i kulturowe"; Czaputowicz, 2013).

Bezpieczeństwo społeczne w literaturze przedmiotu traktowane jest szeroko od patologii społecznych poprzez zabezpieczenie społeczne, pomoc społeczną czy aktywność gospodarczo-społeczną poprawiającą (umożliwiającą) egzystencję życia ludzi.

Analiza Strategii Bezpieczeństwa Narodowego wskazuje, że to państwo przypisuje sobie główną odpowiedzialność za efektywne funkcjonowanie systemu i wskazuje priorytety działań. Ważne staje się określenie związku współzależności poziomu bezpieczeństwa społecznego od skuteczności instytucji. Tak więc procesem analizy powinien być objęty nie tylko stan bezpieczeństwa społecznego w państwie, ale również proces jego „organizowania” oraz zależności z otoczeniem. Takie rozróżnienie pozwala na zróżnicowanie zagrożeń społecznych na zagrożenia społeczne oraz zagrożenia społeczne państwa (Skrabacz, Sulowski, 2012).

Można wskazać za szkołą kopenhaską, że określenie „bezpieczeństwo społeczne" używane jest w znaczeniu społeczno-kulturowym, które odznacza się wysokim stopniem powiązania z jednostką i społeczeństwem.

Drugi obszar bezpieczeństwa społecznego - socjalny - dotyczy pojedynczych ludzi i ekonomicznych aspektów ich życia, przez które tożsamość może wpływać na poziom identyfikacji ze społeczeństwem, poczynając od pełnego uczestnictwa w życiu społecznym, a kończąc na marginalizacji i wykluczeniu (Gierszewski, 2013b). Bezpieczeństwo socjalne wiązane jest $\mathrm{z}$ brakiem lub niedostatkiem materialnych środków utrzymania, które skutkują koniecznością uruchomienia instytucjonalnego systemu zabezpieczenia społecznego, tak aby w razie potrzeby można było liczyć nie tylko na siebie, rodzinę, dobroczynność lub rynek.

Szkoła kopenhaska w obszarze bezpieczeństwa społecznego wydziela dwa obszary tematyczne: społeczno-kulturowy, związany z tożsamością kolektywną (societal security) oraz socjalny, związany z tożsamością indywidualną (social security).

\section{Bezpieczeństwo społeczne w ujęciu systemowym}

W obszarze bezpieczeństwa społecznego zachodzą obecnie istotne zmiany, których następstwa w nadchodzących latach stawać się będą coraz bardziej widoczne. I tak dla przykładu, szybkie starzenie się społeczeństwa stworzy nie tylko wiele problemów gospodarczych i społecznych, ale może stanowić zarzewie potencjalnego konfliktu międzypokoleniowego, dzieląc społeczeństwo na płacących składki oraz beneficjentów systemu zabezpieczenia społecznego. Konflikt ten potęgować może 
zmniejszona dzietność, która w konsekwencji doprowadzi do zmniejszenia potencjalnych „pomocników” rodzinnych, a zwiększenia roli państwa (systemu opieki; Gierszewski, 2012).

Rysunek 1. Elementy bezpieczeństwa społecznego w systemie bezpieczeństwa narodowego

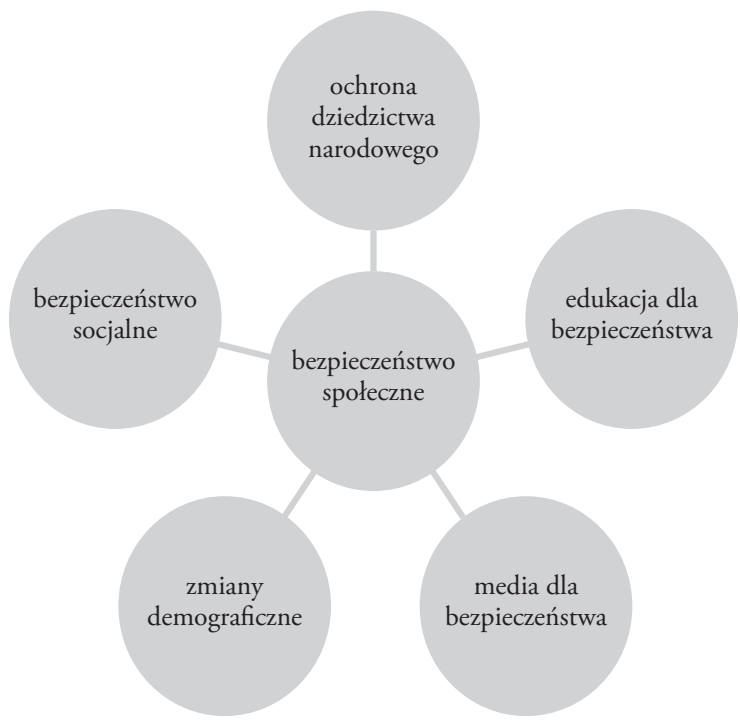

Źródło: opracowanie własne na podstawie: Strategia Bezpieczeństwa Narodowego (2014).

Marek Leszczyński zwraca uwagę na instytucjonalne oddziaływanie państwa w kształtowaniu bezpieczeństwa społecznego. Dzieli bezpieczeństwo społeczne na: socjalne związane z gwarancją minimalnych dochodów oraz transferami socjalnymi, rozwojowe (kapitał ludzki) i wspólnotowe (kapitał społeczny; Leszczyński, 2011).

Natomiast Aleksandra Skrabacz bezpieczeństwo społeczne określa wprost jako jedną z kategorii bezpieczeństwa narodowego, która odnosi się do ochrony egzystencjalnych podstaw życia oraz umożliwia realizację aspiracji życiowych przez tworzenie warunków do pracy i nauki, ochronę zdrowia oraz gwarancje emerytalne (Skrabacz, 2012). Wiąże ona bezpieczeństwo społeczne z bezpieczeństwem socjalnym jako działaniem państwa, które powinno zapewnić minimalny standard, oraz psychospołecznym, które odnosi do stanu psychicznego i społecznego jednostek i grup społecznych gwarantującego stabilny rozwój i realizację podstawowych celów i zadań życiowych oraz zawodowych w warunkach akceptacji i tolerancji społecznej (Skrabacz, 2012). 


\section{Bezpieczeństwo społeczne w ujęciu buman security}

Przywołane definicje ujmują treści bezpieczeństwa społecznego systemowo, podkreślając integralne elementy systemu, takie jak prawo, instytucje czy czynniki rozwoju związane z kapitałem społecznym i ludzkim oraz tożsamością kulturową.

W konsekwencji problemem staje się już samo ustalenie zakresu pojmowania bezpieczeństwa społecznego z perspektywy nie tylko jednostki czy grup społecznych, ale również bezpieczeństwa państwa. Takie podejście koncentruje uwagę na sferze organizacji systemu bezpieczeństwa (Gierszewski, 2015).

„Bezpieczeństwo socjalne” wskazywane jest jako cel zadań realizowanych przez państwo. Wynika to z art. 137 Traktatu ustanawiającego WE i wyraża socjalne potrzeby społeczeństwa w zakresie prawa do świadczeń oraz powinności państwa. Ma wymiar obiektywny, związany z systemem instytucji gwarantujących ład społeczny, oraz subiektywny, wyrażający się w opiniach i zachowaniach społecznych oceniających system.

Bezpieczeństwo społeczne można też powiązać z koncepcją human security (Human Development Report, 1994), koncentrującą się na człowieku, a w szczególności z koniecznością zaspokojenia jego egzystencjalnych potrzeb. Jednak w tej koncepcji głównym podmiotem bezpieczeństwa jest jednostka (człowiek) oraz jego potrzeby, a nie państwo.

Opierając się na sformułowanych wyżej rozważaniach, można przyjąć, że bezpieczeństwo społeczne stanowi trwały element warunkujący bezpieczeństwo państwa, umiejscowione jest w ogólnej problematyce bytu i ma liczne związki oraz zależności z zagrożeniami interesu narodowego oraz potrzebami społecznymi.

Założenie to pozwala zauważyć, że istnieją różne podmioty (nie jeden), których egzystencja jest zagrożona. Jako podmioty bezpieczeństwa stanowią one ciekawy obszar analizy (również aksjologicznej) przedstawicieli różnych dyscyplin naukowych (rys. 2). W tym miejscu można zadać pytanie - który z podmiotów ma większe prawo do przetrwania? w jakich sytuacjach? kto daje legitymację do hierarchizowania społecznych wartości chronionych?

Ważną kwestią staje się przyjęcie odpowiedzialności przez państwo za stabilizowanie sytuacji konfliktowych związanych z niesprawiedliwym rozdziałem dóbr w państwie czy zachowaniami zagrażającymi tożsamości narodowej. Taka sytuacja prowadzi do kolejnego rozróżnienia: na "uprawnionych” (posiadających prawo do dóbr) oraz „zasobów” (ilości dóbr) w państwie (Gierszewski, 2012). Sytuacja konfliktowa będzie oznaczała brak uprawnień (np. do kultywowania tradycji) lub brak dostępu do zasobów (np. pracy) i postrzegana będzie jako zagrożenie dla egzystencji czy tożsamości narodowej. Jednak to głównie państwo będzie postrze- 
gane (z poziomu zagrożonej jednostki czy grupy społecznej) jako podmiot odpowiedzialny za stabilizację konfliktu z uwagi na rolę i pozycję państwa ukształtowaną w świadomości społecznej. Innym problemem jest, czy państwo jest w stanie to bezpieczeństwo na pożądanym poziomie zagwarantować.

Niezależnie od ilości przytoczonych determinantów bezsporny pozostanie fakt wzajemnego przenikania się istotnych wartości tworzących osnowę systemu bezpieczeństwa społecznego, które podlegają szczególnej ochronie. W tym kontekście można założyć, że niedookreślenie tego obszaru jako kategorii bezpieczeństwa narodowego może powodować wśród organów odpowiedzialnych za tę dziedzinę pewne kwestie sporne, a nawet chaos koncepcyjny, a co za tym idzie pogorszenie funkcjonowania instytucji działających w tym obszarze.

Rysunek 2. Wymiary bezpieczeństwa społecznego

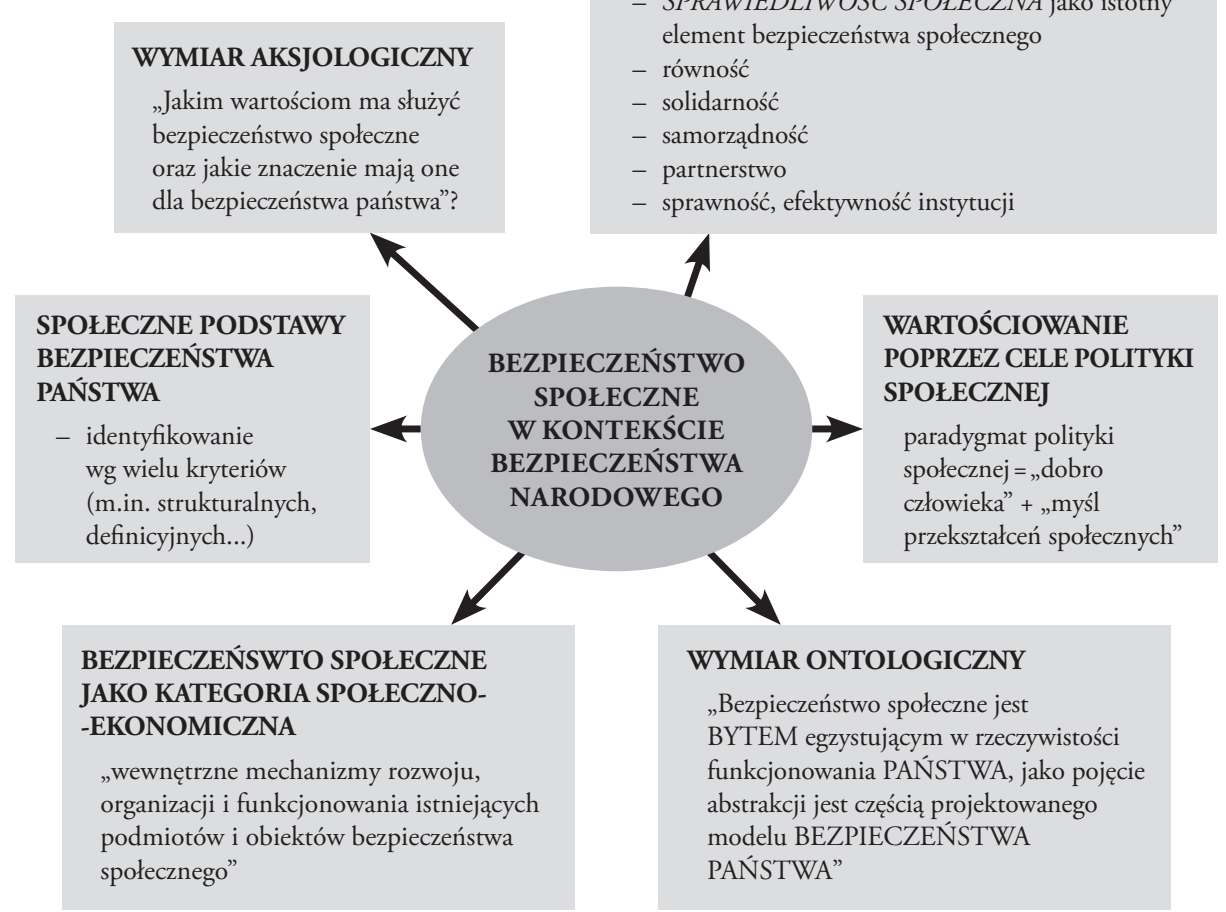

Źródło: opracowanie na podstawie: Gierszewski (2013c). 
System bezpieczeństwa społecznego - uwzględniając wszystkie wymiary oraz rozbudowaną strukturę - powinien w zamyśle tworzyć efekt synergii, zwielokrotniając tym samym korzyści nie tylko dla bezpieczeństwa państwa, ale i całego społeczeństwa. Należy bowiem wskazać, że znaczenie bezpieczeństwa społecznego jako składnika systemu bezpieczeństwa narodowego stale rośnie i ewoluuje.

\section{Bezpieczeństwo społeczne w ujęciu sektorowym i problemy definicyjne}

Podsystem społeczny jest jednym z pięciu podsystemów przygotowań strategicznych bezpieczeństwa Polski. Strategia Bezpieczeństwa Narodowego z 2014 r. zakłada, że w obszarze bezpieczeństwa społecznego istotą działań społecznych państwa jest stwarzanie warunków do godziwego życia oraz rozwoju duchowego i materialnego narodu. Bezpieczeństwo społeczne państwa w takiej sytuacji nie będzie odnosić się tylko do podejmowania działań wewnątrz państwa w sytuacjach nadzwyczajnych, wykraczających poza normalne funkcjonowanie instytucji działających w obszarze bezpieczeństwa społecznego.

Rysunek 3. Sektory bezpieczeństwa społecznego

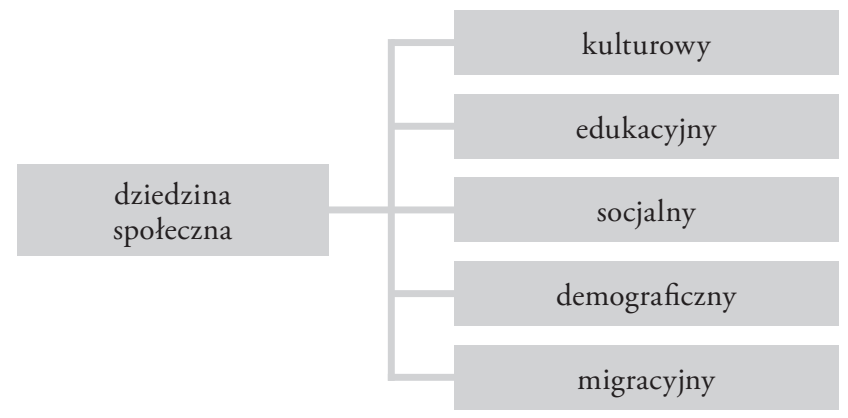

Źródło: opracowanie własne na podstawie: Biała Księga Bezpieczeństwa Narodowego (2013).

Poszukując elementów definiujących bezpieczeństwo społeczne, należy zauważyć, że:

- po pierwsze, bezpieczeństwo społeczne można rozpatrywać szeroko (systemowo) jako aktywność państwa i innych podmiotów kształtujących jakość życia oraz tożsamość narodową w powiązaniu z systemem bezpieczeństwa narodowego, albo wąsko, rozpatrując każdy element oddzielnie, tj. bezpie- 
czeństwo socjalne, bezpieczeństwo tożsamości w oderwaniu od systemu bezpieczeństwa narodowego;

- po drugie, uświadomienie rozległości badanego obszaru, który był do tej pory domeną polityki gospodarczej i społecznej. W pierwszym przypadku wskazywano, że bezpieczeństwo społeczne jest elementem pewnej części z większej całości (gospodarki), a w drugim - podkreślano odróżnienie dwóch względnie równoważnych obszarów. Na te obszary analizy związane z egzystencją oraz tożsamością można nałożyć perspektywę bezpieczeństwa państwa jako wartości nadrzędnej;

- po trzecie, krytyczna analiza literatury przedmiotu pozwala na stwierdzenie, że istnieje widoczna luka w pracach i badaniach systemu bezpieczeństwa społecznego w naukach o bezpieczeństwie (Skrabacz, Sulowski, 2012). Może się to wiązać z tym, że badanie procesów społecznych pod względem ich wpływu na potencjał bezpieczeństwa narodowego jest bardzo trudne;

- po czwarte, definiując pojęcie bezpieczeństwa społecznego na gruncie nauk o bezpieczeństwie wskazuje się na jego powiązania z innymi systemami warunkującymi optymalne funkcjonowanie państwa. Można założyć, że bezpieczeństwo społeczne państwa nie jest tylko zorientowanym na potrzeby ludzkie systemem i różni się od traktowanej wąsko aktywności gospodarczej oraz „trzeciego sektora”. Dlatego zdaniem autora należy rozróżnić „bezpieczeństwa społeczne” od „bezpieczeństwa socjalnego”, które oznacza poziom i sposób zaspokajania podstawowych potrzeb społecznych. W ten sposób można zauważyć, że bezpieczeństwo społeczne wiąże się z realizacja celów - interesów państwa - mających związek z koncepcją strategiczną bezpieczeństwa narodowego;

- po piąte, problemem jest uszczegółowienie przedmiotu i podmiotu badań. W Strategii Bezpieczeństwa Narodowego RP z 2007 r. bezpieczeństwo społeczne wyszczególniono jako istotny element całościowej koncepcji strategicznej. Bezpieczeństwo społeczne ujmowane było w tej strategii nie tylko jako zadanie dla instytucji państwa, ale dla całego społeczeństwa, podmiotów to społeczeństwo organizujących i poszczególnych jednostek. Oczywiście rola państwa jako kreatora bezpieczeństwa społecznego w tym względzie jest dominująca. Wydaje się, że prostą metodą wyodrębnienia bezpieczeństwa społecznego $\mathrm{w}$ ujęciu podmiotowym i przedmiotowym są pytania w rodzaju: kogo bezpieczeństwo społeczne dotyczy? (jednostki, grup społecznych, państwa). Czego bezpieczeństwo społeczne dotyczy? (dziedzictwa narodowego, edukacji dla bezpieczeństwa, mediów zajmujących się problematyką bezpieczeństwa, demografii, pomocy społecznej czy zabezpieczenia społecznego); 
- po szóste, ogromna liczba zagrożeń społecznych, które są opisywane w literaturze przedmiotu. Istotne wydaje się odróżnienie zagrożeń społecznych zagrażających podmiotowi bezpieczeństwa, jakim jest państwo, od kwestii czy problemów społecznych zagrażających jednostkom i grupom społecznym w państwie.

Uwagi te wskazują, że skomplikowana materia bezpieczeństwa społecznego wymaga określenia jej miejsca i roli w systemie bezpieczeństwa narodowego. Jeżeli za główny klucz do zrozumienia bezpieczeństwa społecznego uznamy kwestie bezpieczeństwa państwa, to - w uproszczeniu - teoria bezpieczeństwa społecznego będzie po prostu teorią bezpieczeństwa społecznego państwa.

\section{Bezpieczeństwo społeczne w ujęciu państwocentrycznym}

Punktem wyjścia dla definiowania bezpieczeństwa społecznego państwa moga być na pierwszym miejscu interesy państwa, potem grup społecznych, a na końcu pojedynczego człowieka.

Hierarchię pojęć: bezpieczeństwo państwa, bezpieczeństwo społeczne i bezpieczeństwo socjalne przedstawia rysunek rys. 4. Bezpieczeństwo społeczne powiązane jest z podmiotami bezpieczeństwa wyodrębnionymi w naukach o bezpieczeństwie, tj. człowiekiem, grupami społecznymi i państwem. Odwołuje się głównie do takich wartości jak przetrwanie i tożsamość narodowa. Znajduje to potwierdzenie w podmiotowo-przedmiotowym modelu analizy bezpieczeństwa (Cieślarczyk, Kuriata, 2005).

Rysunek 4. Elementy bezpieczeństwa społecznego w ujęciu wertykalnym

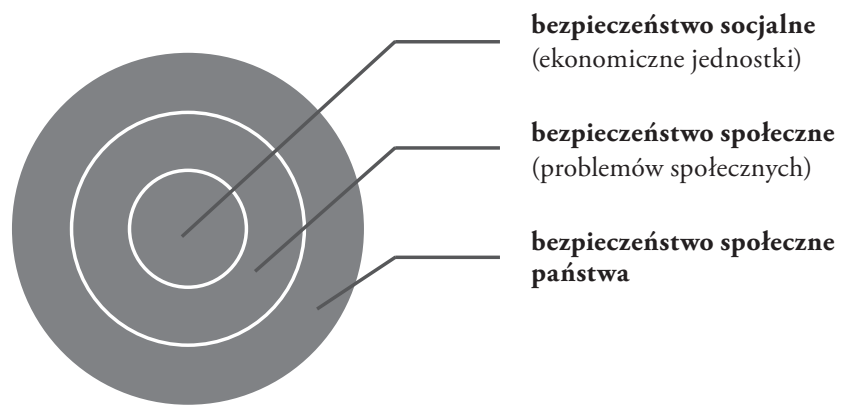

Źródło: opracowanie własne z inspiracji Buzan, Waever, de Wilde (1998). 
Bezpieczeństwo socjalne oznacza ochronę, którą dostarcza państwo swoim członkom poprzez zapobieganie ekonomicznej i społecznej nędzy, która może być powodowana redukcją zarobków, chorobą, macierzyństwem, dyskryminacją w sektorze zatrudnienia, bezrobociem, niepełnosprawnością, podeszłym wiekiem i śmiercią (Social Security and the Rule of Law, 2011). Bezpieczeństwo socjalne jest traktowane jako obowiązek państwa (administracji publicznej) do gwarantowania świadczeń socjalnych.

Bezpieczeństwo społeczne oznacza ochronę od niedostatku materialnych i duchowych potrzeb oraz gwarantuje możliwość swobodnego rozwoju jednostek w państwie. Obejmuje nie tylko stan wolności od różnych rodzajów ryzyk socjalnych (Leksykon polityki społecznej, 2001), ale całej gamy problemów społecznych z uwzględnieniem tożsamości narodowej.

Bezpieczeństwo społeczne państwa oznacza działalność państwa zmierzającą do neutralizowania problemów społecznych, a mającą na celu zapewnienie egzystencji, ochronę dziedzictwa narodowego oraz odpowiedniej jakości życia mieszkańcom przez wykorzystanie wewnętrznych i zewnętrznych czynników gwarantujących niezagrożony rozwój narodu oraz ład społeczny, którego zakłócenie może spowodować zagrożenie stabilności wewnętrznej państwa.

Przyjmując jako odniesienie do systemu bezpieczeństwa narodowego, system bezpieczeństwa społecznego państwa postrzegany będzie przez pryzmat realizowanej przez niego funkcji jako podsystem społeczny stanowiący wsparcie systemu bezpieczeństwa narodowego.

Założenie to ma walor uniwersalny, chociaż środowisko bezpieczeństwa może zweryfikować sposoby organizacji systemu, wyrażając się w preferowaniu innych kategorii bezpieczeństwa, przyjętych w kolejnej strategii bezpieczeństwa narodowego.

Bezpieczeństwo społeczne odwołuje się w sposób pośredni do bezpieczeństwa publicznego jako gwarancji niezakłóconego funkcjonowania instytucji publicznych oraz mieszkańców w państwie (Misiuk, 2008; Sulowski-Brzeziński, 2009). W literaturze przedmiotu brak jednoznacznych, powszechnie obowiązujących stwierdzeń określających, czy bezpieczeństwo społeczne jest pojęciem związanym $\mathrm{z}$ bezpieczeństwem publicznym. Autor uważa, że istotą w tym obszarze są działania ochronne podejmowane przez administrację publiczną (system kierowania) na rzecz zagwarantowania określonego poziomu bezpieczeństwa wewnątrz państwa przez zaspokojenie potrzeb gwarantujących ład społeczny. Niektórzy znawcy problematyki już w latach 90. wskazywali wprost, że źródeł zagrożeń bezpieczeństwa publicznego dopatrywać się można m.in. w wysokim poziomie bezrobocia, rozwarstwieniu ekonomicznym, wzroście migracji zewnętrznej, osłabieniu więzi spo- 
łecznych czy poczuciu marginalizacji dużych grup społecznych, a więc w problemach społecznych (Pokruszyński, Straszewski, Terlikowski, 1996).

Bezpieczeństwo społeczne to stan i proces, który zapewnia spójność celów bezpieczeństwa narodowego związanych z gwarancją przetrwania, dobrobytu oraz zrównoważonego rozwoju społeczeństwa. Oparte jest na powszechnie uznanych wartościach oraz normach prawnych związanych z trwaniem państwa i jego rozwojem. W ten sposób nawiązuje do wyróżnionych przez Józefa Kukułkę celów podstawowych związanych z egzystencją (maksymalizacją szans przetrwania, czyli potrzebami) oraz potrzebami (aktywnością i rozwojem podmiotu bezpieczeństwa; Kukułka, 1978).

Konstytucja RP określa w preambule wartości priorytetowe dla polskiego społeczeństwa, które wprowadzone w życie decydują o harmonijnym funkcjonowaniu bytu państwowego. Spośród wartości większość badaczy wyróżnia cztery podstawowe: przetrwanie (dla tej wartości społeczeństwa są skłonne w określonych sytuacjach poświęcić inne), integralność terytorialną, suwerenność oraz jakość życia.

Poszczególne narody i państwa decydują indywidualnie o hierarchii wartości, które powinny być chronione w ramach przyjętych priorytetów określonych np. w strategii bezpieczeństwa narodowego, i wskazują adekwatne środki do ich realizacji. Ich dobór zależy od rodzaju i skali zagrożeń oraz możliwości państwa, jego koncepcji opartej na wspomnianych wartościach i zasadach (Karp, 2009).

Niezaspokojone potrzeby, brak zasobów, poczucie niesprawiedliwego podziału dóbr, pogorszenie warunków bytowych, problemy z emigrantami, utrudniony dostęp do świadczeń socjalnych czy brak perspektyw życiowych mogą wzbudzić niezadowolenie w społeczeństwie, wzniecić wewnętrzne niepokoje czy masowe wystąpienia - destabilizując w ten sposób ład społeczny w państwie.

Bezpieczeństwo społeczne to system oparty na subsydiarności, którego funkcjonowanie zależy przede wszystkim od aktywności państwa, rynku (dóbr i usług), grup wspólnotowych oraz aktywności własnej jednostki. W pierwszym rzędzie chodzi o szeroko pojęte potrzeby/interesy ekonomiczne. Stanowią one część umowy społecznej w zakresie dystrybucji dóbr i usług. W formie państwowej miało być środkiem do przezwyciężenia niedostatków (niebezpieczeństw ekonomicznych), na jakie był narażony człowiek.

Jednym ze sposobów określenia roli państwa w systemie bezpieczeństwa społecznego może być analiza wydatków publicznych, tj. na jakie cele przeznaczane są środki z budżetu państwa na bezpieczeństwo społeczne (ubezpieczenia społeczne czy wydatki socjalne).

To głównie państwo gwarantuje (lub nie) sprawiedliwą redystrybucję dóbr materialnych i usług oraz zabezpieczenie społeczne. Szczególne znaczenie ma to w sy- 
tuacji, gdy współczesne zagrożenia sprzyjają rozwarstwieniu społecznemu i konfliktom na tym tle (Gierszewski, 2013b).

W systemowym postrzeganiu bezpieczeństwa społecznego państwa możliwe jest przeniesienie „obronnej” perspektywy badawczej na kwestie bezpieczeństwa społecznego (na „wsparcia”). Dzięki temu można rozpatrywać bezpieczeństwa społeczne przez pryzmat zdolności systemu do zapobiegania różnorodnym konfliktom wewnątrz państwa.

Bsp: Po $=\mathrm{Zs}(\mathrm{k})$

Bezpieczeństwo społeczne państwa (Bsp) oznacza stan równowagi między potencjałem systemu wsparcia (Po) a zagrożeniami społecznymi wywołującymi konflikt $[\mathrm{Zs}(\mathrm{k})]$.

Koniecznym zatem zabiegiem w celu dokonania identyfikacji i oceny zagrożeń społecznych staje się przewidywanie powstawania w określonej perspektywie sytuacji konfliktowych, a także hipotetycznych skutków przyszłych konfliktów społecznych w państwie wywoływanych przez te zagrożenia. Dzięki takiemu rozumowaniu można przyjąć, że bezpieczeństwo społeczne państwa to stan, w którym potencjał zagrożeń społecznych, skorygowany prawdopodobieństwem zaistnienia konfliktu (pk), nie przewyższa potencjału systemu bezpieczeństwa społecznego państwa (Gierszewski, 2013c).

Bsp: $\mathrm{Pz}(\mathrm{s}) \cdot \mathrm{pk} \leq \mathrm{Po}$

Każda zmiana w systemie, nawet wprowadzana w imię interesów narodowych (np. podniesienie wieku emerytalnego), prowadzi często do rozmaitych napięć strukturalnych, na które nakładają się różne problemy (kryzys gospodarczy, procesy demograficzne).

Istnieje zawsze realna groźba załamania się elementu systemu, a to może spowodować powstanie sytuacji kryzysowej (protesty społeczne) i zagrożenie destabilizacją ładu społecznego. Sprawny system bezpieczeństwa społecznego państwa niewątpliwie przyczynia się do utrzymania bezpieczeństwa wewnątrz państwa.

\section{Zakończenie}

System bezpieczeństwa społecznego państwa osadzony jest w konkretnych ramach prawno-organizacyjnych kształtujących system na różnych poziomach zorganizowania państwa. Natomiast efekty skuteczności systemu są pochodną aktywności instytucjonalnej i możliwości gospodarczych państwa, a nie tylko aktywności jed- 
nostki. Dlatego problematykę radzenia sobie z zagrożeniami społecznymi państwa rozpatrywać należy ze szczególnym uwzględnieniem efektywności instytucji publicznych (systemu kierowania i wsparcia).

W miejsce państwa jako pojedynczego aktora procesu tworzenia systemu bezpieczeństwa społecznego coraz częściej bierze się pod uwagę cały układ pozarządowych instytucji zorganizowanych na różnych poziomach. Istnieje jednak niebezpieczeństwo, że państwo, przekazując coraz większą liczbę zadań z tego obszaru, może doprowadzić do przeciążenia nimi struktur samorządowych.

Rozwój, czy nawet wypływające z refleksji teoretycznej prognozowane kierunki przemian społecznych wymuszają włączanie do systemu bezpieczeństwa społecznego instytucji prywatnych czy ponadnarodowych. $\mathrm{Na}$ szczególną uwagę zasługuje przenikanie się systemu bezpieczeństwa społecznego z innymi ponadnarodowymi systemami.

Bezpieczeństwo społeczne jako jedna z dziedzin bezpieczeństwa narodowego we obecnych czasach nabiera szczególnego znaczenia.

\section{Bibliografia:}

Biernat, T., Gierszewski, J. (2013). Poczucie bezpieczeństwa społecznego młodzieży w matym środowisku. Toruń: Akapit.

Brzeziński, M. (2009). Rodzaje bezpieczeństwa. W: S. Sulowski, M. Brzeziński (red.), Bezpieczeństwo wewnętrzne pañstwa. Wybrane zagadnienia. Warszawa: Dom Wydawniczy Elipsa.

Buzan, B., Waever, O., de Wilde, J. (1998). Security: A New Framework for Analysis. Boulder: Lynne Rienner Publishers

Cieślarczyk, M., Kuriata, R. (2005). Kryzysy i sposoby radzenia sobie z nimi. Łódź: Wydawnictwo Naukowe Wyższej Szkoły Kupieckiej.

Czaputowicz, J. (2003). Kryteria bezpieczeństwa międzynarodowego państwa - aspekty teoretyczne. W: S. Dębski, B. Górka-Winter (red.), Kryteria bezpieczeństwa międzynarodowego panstwa. Warszawa: PISM.

Dębski, S., Górka-Winter, B. (red.). (2003). Kryteria bezpieczeństwa międzynarodowego państwa. Warszawa: PISM.

Floyd, R. (2007). Human Security and the Copenhagen School's Securitization Approach: Conceptualizing Human Security as a Securitizing Move. Human Security Journal, vol. 5, Winter.

Gierszewski, J. (2011). Społeczne zagrożenia (social security) bezpieczeństwa państwa. W: L. Grochowski, A. Letkiewicz, A. Misiuk (red.), Nauka o bezpieczeństwie. Istota, przedmiot badań i kierunki rozwoju. Studia i materiaty, T. 2. Szczytno: Wydawnictwo Wyższej Szkoły Policji. 
Gierszewski, J. (2012). Model bezpieczeństwa społecznego na tle teorii konfliktu. W: J. Teska (red.), Bezpieczeństwo wewnętrzne i ochrona infrastruktury krytycznej, T. II. Gdynia: Wydawnictwo J.P.

Gierszewski, J. (2013a). Organizacja systemu bezpieczeństwa społecznego. Warszawa: Difin. Gierszewski, J. (2013b). Wykluczenie społeczne a bezpieczeństwo państwa. W: M. Chrabkowski, C. Tatarczuk, J. Tomaszewski (red.), Bezpieczeństwo w administracji, gospodarce $i$ biznesie. Aksjologia zjawisk kryzysowych $w$ administracji $i$ sektorze publicznym. Gdynia: Wyższa Szkoła Administracji i Biznesu im. Eugeniusza Kwiatkowskiego.

Gierszewski, J. (2013c). Bezpieczeństwo społeczne. Studium z zakresu teorii bezpieczeństwa narodowego. Warszawa: Difin.

Gierszewski, J. (2015). Bezpieczeństwo socjalne, społeczne a bezpieczeństwo społeczne państwa w ujęciu systemowym i sekurytyzacji. W: M. Chrabkowski, C. Tatarczuk, J. Tomaszewski, W. Wosek (red.), Bezpieczeństwo w administracji i biznesie jako czynnik europejskiej integracji i rozwoju. Gdynia: Wyższa Szkoła Administracji i Biznesu im. Eugeniusza Kwiatkowskiego.

Gierszewski, J., Piwowarski, J. (2016). Theoretical Basics of Societal Security. Security Dimensions International \& National Studies, NO. 18.

Hofreiter, L. (2012). Wstęp do studiów bezpieczeństwa. Kraków: Krakowskie Towarzystwo Edukacyjne - Oficyna Wydawnicza AFM.

Human Development Report. (1994). United Nations Development Programme (UNDP) Oxford University Press: New York-Oxford.

Karp, J. (2009). Bezpieczeństwo państwa. W: W. Skrzydło, S. Grabowska, R. Grabowski (red.), Konstytucja Rzeczypospolitej Polskiej. Komentarz encyklopedyczny. Warszawa.

Kitler, W. (2010). Bezpieczeństwo narodowe. Podstawowe kategorie, dylematy pojęciowe i próba systematyzacji. Towarzystwo Wiedzy Obronnej, Zeszyt Problemowy, nr 1(61).

Kitler, W. (2011). Bezpieczeństwo narodowe RP. Podstawowe kategorie. Uwarunkowania. System. Warszawa: AON.

Kowalczyk, B. (red.). (2001). Leksykon polityki społecznej. Warszawa: Oficyna Wydawnicza ASPRA-JR.

Kukułka, J. (1978). Problemy teorii stosunków międzynarodowych. Warszawa: Państwowe Wydawnictwo Naukowe.

Kukułka, J. (1982). Bezpieczeństwo a współpraca europejska: współzależności i sprzeczności interesów. Sprawy Międzynarodowe, z. 7.

Leszczyński, M. (2011). Bezpieczeństwo społeczne Polaków wobec wyzwań XXI wieku. Warszawa: Difin.

Misiuk, A. (2008). Administracja porzadku i bezpieczeństwa publicznego: zagadnienia prawno-ustrojowe. Warszawa: Wydawnictwa Akademickie i Profesjonalne.

Misiuk, A. (2013). Rzecz o bezpieczeństwie - geneza, istota i rozwój. e-Politikon, nr 6.

Orzeczenie TK z 19 listopada 1996 r., K 7/95, OTK 1996.

Pokruszyński, W., Straszewski, K., Terlikowski, T. (1996). System bezpieczeństwa publicznego Polski. Warszawa: AON.

Skrabacz, A. (2012). Bezpieczeństwo społeczne. Podstawy teoretyczne i praktyczne. Warszawa: Dom Wydawniczy Elipsa. 
Skrabacz, A., Sulowski, S. (2012). Bezpieczeństwo społeczne. Pojęcie - uwarunkowaniawyzwania. Warszawa: Dom Wydawniczy Elipsa.

Skrzydło, W., Grabowska, S., Grabowski R. (red.). (2009). Konstytucja Rzeczypospolitej Polskiej. Komentarz encyklopedyczny. Warszawa: Wolters Kluwer.

Social Security and the Rule of Law. General Survey Concerning Social Security Instruments in Light of the 2008 Declaration on Social Justice for a Fair Globalization. Report of the Committee of Experts on Application of Conventions and Recommendations. (2011). Pobrane z: http://www.ilo.org/global/standards/WCMS_152909/lang--en/index.htm.

Strategia Bezpieczeństwa Narodowego. (2007). Warszawa: Biuro Bezpieczeństwa Narodowego.

Strategia Bezpieczeństwa Narodowego. (2014). Warszawa: Biuro Bezpieczeństwa Narodowego.

Ustawa z dnia 4 września 1997 r. o działach administracji rządowej (t.j. Dz.U. z 2017 r. poz. 888,1086$)$.

Weaver, O., Buzan, B., Kelstrup, M., Lemaitre, P. (1993). Identity, Migration and the New Security Agenda in Europe. London: Palgrave Macmillan. 